\title{
PENGARUH PENGAKUAN PENDAPATAN DAN BEBAN PERUSAHAAN TERHADAP LAPORAN LABA RUGI PADA PERUSAHAAN KONSTRUKSI PT. SUMBER BAROKAH
}

\author{
Wiji Lestari \\ Indira Shinta Dewi, SE.,AK.,MM \\ Program Studi Fakultas Ekonomi Universitas Satya Negara Indonesia
}

\begin{abstract}
ABSTRAK
Setiap perusahaan memiliki tujuan untuk memaksimalkan laba atau keuntungan. Laba merupakan selisih antara pendapatan yang diterima dengan beban yang dikeluarkan oleh perusahaan. Oleh karena itu pendapatan yang diterima oleh perusahaan harus diukur secara wajar dan sesuai dengan prinsip serta standard yang berlaku umum. Dalam perusahaan konstruksi pengakuan pendapatan dan beban diatur dalam PSAK No. 34 mengenai kontrak konstruksi. Pengakuan pendapatan dan beban perusahaan konstruksi terdapat dua metode yaitu persentase penyelesaian dan kontrak selesai. Metode persentase penyelesaian memiliki dasar pengukuran untuk menentukan besarnya persentase penyelesaian yang telah dicapai, yaitu dengan ukuran input dan ukuran output.

Penulis melakukan penelitian pada perusahaan konstruksi PT. Sumber Barokah, hasil penelitian diperoleh bahwa perusahaan menggunakan metode persentase penyelesaian dengan ukuran output dalam pengakuan pendapatannya dan juga menerapkan metode accrual basic dalam pengakuan setiap transaksinya. Penurunan dan kenaikan laba yang dialami setiap tahunnya atas proyek yang dilakuakan dikarenakan perbedaan persentase pendapatan dan beban setiap terminnya. Dengan menerapkan persentase penyelesain dalam pengakuan pendapatan dan bebannya dapat diketahui laporan laba rugi yang disajikan oleh perusahaan sudah memenuhi prinsip matching concept dimana pendapatan yang diakui terdapat pula biaya yang diakui perusahaan.
\end{abstract}

Kata kunci : Pengakuan Pendapatan dan Beban, PSAK No. 34, Persentase Penyelesaian.

PENDAHULUAN

Jurnal Ilmiah Akuntansi dan Ekonomi Volume .1. No. 1 Maret 2016 


\section{Latar Belakang}

Perlakuan akuntansi pendapatan perusahaan konstruksi berhubungan dengan kontrak konstruksi. Pendapatan atas kontrak konstruksi adalah nilai yang muncul atas aktivitas kontrak konstruksi kerjasama antara dua pihak, dimana pihak pertama adalah pihak yang memberi kontrak kerja konstruksi (pelanggan) dan pihak kedua adalah pihak yang menerima dan menjalankan kontrak konstruksi/penerima kontrak. (M. Nuruzzaman dan Agus Setiady, 2009)

Dalam hal pengakuan pendapatan dan beban dari perusahaan konstruksi sesungguhnya telah diatur dalam Pernyataan Standard Akuntansi Keuangan (PSAK) No. 34 (Revisi 2010), dalam pernyataan tersebut dinyatakan bahwa, " kontrak konstruksi adalah suatu kontrak yang dinegosiasikan secara khusus untuk konstruksi suatu aset atau suatu kombinasi aset yang berhubungan erat satu sama lain atau saling tergantung dalam hal rancangan, teknologi, dan fungsi atau tujuan pokok penggunaan".

Terdapat dua metode pengakuan pendapatan dan beban perusahaan konstruksi, yaitu metode persentase penyelesaian dan metode kontrak selesai. Metode persentase penyelesaian mengakui pendapatan, biaya, dan laba kotor sesuai dengan persentase pekerjaan yang telah diselesaikan dalam tiap periode. Metode kontrak selesai mengakui pendapatan apabila kontrak telah selesai dikerjakan.

(Skousen, 2004:592)

Penerapan metode pengakuan dan beban mempunyai pengaruh dalam perhitungan laba rugi perusahaan, apabila penerapan metode pengakuan pendapatan dan beban tidak tepat maka akan menyajikan laporan keuangan yang tidak mencerminkan kinerja perusahaan yang sesungguhnya. Ketepatan perlakuan akuntansi dalam mengakui pendapatan dan beban sangat berpengaruh pada kewajaran yang dilaporkan dalam laporan laba rugi periodik, dimana laporan laba rugi periodik melaporkan besarnya pendapatan dan pembebanan biaya yang diakui dalam satu periode.

\section{Perumusan Masalah}

1. Bagaimana pengaruh pengakuan pendapatan dan beban terhadap laporan laba rugi pada PT. Sumber Barokah?

2. Apakah pengakuan pendapatan dan beban serta pengaruhnya terhadap laporan laba rugi PT. Sumber Barokah telah sesuai dengan PSAK No. 34 (Revisi 2010)?

\section{LANDASAN TEORI}

\section{Metode Pengakuan Pendapatan dan Beban}

\section{Metode Persentase Penyelesaian}

Dalam metode ini pengakuan pendapatan dan beban atas suatu proyek didasarkan pada tingkat kemajuan penyelesaian pekerjaannya, dalam arti dalam bahwa pengakuan laba atau rugi suatu proyek dapat dihitung walaupun proyeknya belum selesai dikerjakan.

Untuk mengukur tingkat penyelesaian pekerjaan suatu proyek sampai suatu saat tertentu atau pada saat penyusunan laporan keuangan, biasanya didasarkan pada berikut:

a. Ukuran Input merupakan ukuran yang dibuat dalam hubungannya dengan biaya atau usaha yang digunakan untuk suatu kontrak. Ukuran ini didasarkan pada hubungan yang ditetapkan atau yang diasumsikan antara satu unit input dengan produktivitas. Ukuran ini meliputi metode: 
1. Metode biaya ke biaya ( cost- to- cost method)

2. Metode upaya yang dikeluarkan (effoort-expended methods)

b. Ukuran output, merupakan ukuran yang dibuat dalam hal hasil yang dicapai. Termasuk dalam kategori ini adalah metode-metode yang didasarkan pada unit yang diproduksi, tahapan-tahapan kontrak yang dicapai, dan nilai tambah.

Keuntungan dari penggunaan metode persentase penyelesaian adalah sebagai berikut:

a. pendapatan diakui secara periodik sesuai dengan pekerjaan yang telah diselesaikan, sehingga dapat dilakukannya konsep matching cost terhadap revenue secara periodik.

b. Laba dari kontrak yang belum selesai dapat ditentukan secara jelas melihat estimasiestimasi yang harus dilakukan terhadap biaya-biaya penyelesaian.

Kelemahan dari penggunaan metode persentase penyelesaian adalah sebagai berikut:

a. Metode ini menganggap profit timbul karena biaya yang dikeluarkan, sedangkan kegiatan yang penting mungkin terjadi pada tingkat perencanaan yaitu sebelum biaya yang besar dikeluarkan

b. Persentase penyelesaian dihitung dengan menggunakan biaya total proyek sebagai penyebut, padahal biaya total ini merupakan sesuatu yang tidak diketahui dengan pasti. Biaya total proyek kebanyakan baru diketahui setelah proyek selesai.

\section{Metode Kontrak Selesai}

Dengan menggunakan metode ini, pendapatan suatu proyek baru dpat diakui apabila kontrak telah selesai dikerjakan, serta biaya- biaya yang masih harus menjadi beban jumlah tidak material lagi. Jadi metode ini menekan ketelitian kecermatan dalam pengakuan pendapatan perusahaan.

Kelebihan dari metode kontrak selesai adalah pelaporan didasarkan pada hasil akhir dan bukan pada taksiran pekerjaan yang belum dilakukan. Kekurangannya adalah tidak mencerminkan prestasi kerja masa berjalan bila periode kontrak tersebut diperpanjang menjadi lebih dari satu periode akuntansi.

\section{Metode Pencatatan Pengakuan Pendapatan Kontrak Konstruksi Jangka Panjang}

\section{Metode Kontrak Selesai}

Pencatatan tagihan atas kemajuan adalah sebagai berikut :

$\begin{array}{lc}\text { Dr.Konstruksi Dalam Proses } & \mathrm{xxx} \\ \text { Cr. Kas } & \mathrm{xxx} \\ \text { Dr. Piutang Usaha } & \mathrm{xxx}\end{array}$

Cr. Tagihan atas Kontrak $\quad$ xxx

Perolehan tagihan atas kemajuan setiap tahun:

Dr. Kas

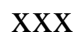

Cr. Piutang Usaha

$\mathrm{XXX}$

Ayat jurnal untuk mengakui pendapatan dan beban atas penyelesaian kontrak adalah sebagai berikut : 
Dr. Tagihan atas Kontrak $\quad$ xxx

Cr. Pendapatan dari Kontrak Jangka Panjang $\quad$ xxx

Dr. Biaya Konstruksi $\quad$ xxx

Cr. Konstruksi Dalam Proses $\quad$ xxx

Pada penyelesaian kontrak, laba diakui sebagai perbedaan antara saldo akumulasi tagihan dengan saldo akumulasi persediaan konstruksi dalam proses, dengan asumsi bahwa total harga kontrak telah ditagih.

\section{Metode Persentase Penyelesaian}

Dalam metode presentase penyelesaian ayat jurnal untuk mencatat biaya yang terjadi atas konstruksi, tagihan atas kemajuan dan perolehan tagihan atas kemajuan adalah sama dengan metode kontrak selesai. Ayat jurnal tambahan diperlukan untuk mencatat pengakuan dan beban setiap periode. (laba kotor di debet ke persediaan konstruksi dalam proses).

Dr Biaya Konstruksi $\quad$ xxx

Dr Konstruksi Dalam Proses $\quad$ xxx

Cr Pendapatan Kontrak Jangka Panjang $\quad$ xxx

Ayat jurnal penutup yang dibutuhkan untuk memindahkan biaya kontrak dan tagihan atas kemajuan pada penyelesaian proyek adalah sebagai berikut :

Dr Pendapatan atas Kontrak xxx

Cr Kontrak Konstruksi Dalam Proses $\quad$ xxx

\section{METODOLOGI PENELITIAN}

\section{Metode Penelitian}

Jenis penelitian ini menggunakan pendekatan studi deskriptif yang menggambarkan bagaimana pengakuan pendapatan dan beban terhadap laporan keuangan menurut PSAK No. 34 tentang akuntansi kontrak konstruksi.

\section{Waktu Dan tempat Penelitian}

Penulis mengadakan penelitian pada perusahaan konstruksi PT. Sumber Barokah yang beralamat di Jl. Inpres V No. 31 Ciledug Tangerang.

Waktu dalam penelitian ini adalah bulan Oktober - Desember 2014 dan data yang diteliti yaitu berupa kontrak kerja konstruksi dengan PT. Mega Bakti Sarana.

\section{Jenis Data}

Data yang digunakan dalam penelitian ini adalah data sekunder berupa data transaksi salah satu pekerjaan Proyek Pembangunan Ciamis Mall yang dilaksanakan dari tahun 2011 hingga tahun 2013.

\section{HASIL DAN PEMBAHASAN}


PT. Sumber Barokah dalam menetapkan pengakuan pendapatan kontrak jangka panjang adalah dengan menggunakan metode persentase penyelesaian.

Sebagai gambaran, penulis mengambil salah satu kontrak konstruksi yang telah diselesaikan oleh PT. Sumber Barokah, yaitu pembangunan Ciamis Mall, dengan periode penyelesaian selama 3 periode akuntansi atau selama 3 tahun dengan termin yang disepakati selama 5 kali termin dengan uang muka yang dibayarkan terlebih dahulu $20 \%$ dari nilai kontrak. Nilai kontrak pada pembangunan Ciamis Mall sebesar Rp 4.302.525.500,- . Adapun rincian lima kali termin pembayaran tersebut adalah sebagai berikut:

1. Termin I $10 \%$ dari nilai kontrak dengan tingkat penyelesaian mencapai $30 \%$

2. Termin II $30 \%$ dari nilai kontrak dengan tingkat penyelesaian mencapai $60 \%$

3. Termin III $20 \%$ dari nilai kontrak dengan tingkat penyelesaian mencapai $80 \%$

4. Termin IV $15 \%$ dari nilai kontrak dengan tingkat penyelesaian mencapai $95 \%$

5. Termin V 5\% dari nilai kontrak dengan tingkat penyelesaian mencapai $100 \%$

\section{Pengukuran Pendapatan}

Tabel 1

Pendapatan Proyek

\begin{tabular}{|c|c|c|c|}
\hline No & Ket & Nilai Kontrak & $\begin{array}{c}\text { Jumlah } \\
\text { Pendapatan }\end{array}$ \\
\hline 1 & $\begin{array}{c}\text { Uang Muka } \\
(20 \%)\end{array}$ & $\operatorname{Rp} 4.302 .525 .500$ & $\mathrm{Rp} \quad 860.505 .100$ \\
\hline 2 & $\begin{array}{c}\text { Termin I } \\
(10 \%)\end{array}$ & $\operatorname{Rp} 4.302 .525 .500$ & $\mathrm{Rp} \quad 430.252 .550$ \\
\hline 3 & $\begin{array}{c}\text { Termin II } \\
(30 \%)\end{array}$ & $\operatorname{Rp} 4.302 .525 .500$ & $\operatorname{Rp} 1.290 .757 .650$ \\
\hline 4 & $\begin{array}{l}\text { Termin III } \\
(20 \%)\end{array}$ & $\operatorname{Rp} 4.302 .525 .500$ & $\mathrm{Rp} \quad 860.505 .100$ \\
\hline 5 & $\begin{array}{c}\text { Termin IV } \\
(15 \%)\end{array}$ & $\operatorname{Rp} 4.302 .525 .500$ & $\mathrm{Rp} \quad 645.378 .825$ \\
\hline 6 & $\begin{array}{c}\text { Termin V } \\
(5 \%)\end{array}$ & $\operatorname{Rp} 4.302 .525 .500$ & $\mathrm{Rp} \quad 215.126 .275$ \\
\hline & Total & - & Rp 4.302.525.500 \\
\hline
\end{tabular}

Pendapatan jasa konstruksi diukur sesuai dengan persentase penyelesaian yang dicapai oleh perusahaan.

Pada saat termin I persentase penyelesaian mencapai 30\%, dan pendapatan yang diterima saat termin I juga sebesar 30\% dari nilai kontrak ( uang muka (20\%) + Termin I (10\%) ).

Termin II persentase penyelesaian mencapai $60 \%$, maka pendapatan yang diterima oleh perusahaan juga sebesar $60 \%$ dari nilai kontrak ( uang muka $(20 \%)+$ Termin I (10\%) + Termin II $(30 \%))$.

Termin III persentase penyelesaian mencapai $80 \%$, maka pendapatan yang diterima oleh perusahaan juga sebesar $80 \%$ dari nilai kontrak ( uang muka (20\%) + Termin I (10\%) + Termin II $(30 \%)+$ Termin III (20\%) ). 
Di termin ke IV persentase penyelesaian mencapai 95\%, maka total pendapatan yang diterima juga sebesar $95 \%$ ( uang muka $(20 \%)+$ Termin I (10\%) + Termin II (30\%) + Termin III $(20 \%)+$ Termin IV $(15 \%))$.

Di termin ke V persentase penyelesaian mencapai $100 \%$, maka total pendapatan yang diterima perusahaan juga sebesar $100 \%$ (uang muka $(20 \%)+$ Termin I (10\%) + Termin II $(30 \%)+$ Termin III $(20 \%)+$ Termin IV ( 15\%) + Termin V (5\%) ).

\section{Tabel 2}

Kas yang diterima perusahaan

\begin{tabular}{|c|l|l|}
\hline No & \multicolumn{1}{|c|}{ KET } & $\begin{array}{c}\text { JUMLAH } \\
\text { PENDAPATAN }\end{array}$ \\
\hline 1 & Uang Muka & $\operatorname{Rp~920.740.457,-}$ \\
\hline 2 & Termin I & $\operatorname{Rp~460.370.229,-~}$ \\
\hline 3 & Termin II & $\operatorname{Rp~1.381.110.686,-~}$ \\
\hline 4 & Termin III & $\operatorname{Rp~920.740.457,--~}$ \\
\hline 5 & Termin IV & $\operatorname{Rp~} 690.555 .343,-$ \\
\hline 6 & Termin V & $\operatorname{Rp~230.185.114,--~}$ \\
\hline & Total & $\operatorname{Rp~4.603.702.286,--}$ \\
\hline
\end{tabular}

Nilai kontrak atas proyek Ciamis Mall yang disepakati oleh perusahaan dan pemberi kerja tidak termasuk PPN dan Pph, maka dari itu kas yang diterima oleh perusahaan lebih dari nilai kontrak yang telah disepakati. Kas yang diterima oleh perusahaan berdasarkan besarnya persentase pembayaran yang telah disepakati dalam kontrak kerja ditambah dengan PPN dan dikurangi Pph Final ( Pph Psl 23).

\section{Pencatatan Pendapatan}

\section{Pembayaran Uang Muka}

Perhitungan:

Pengajuan Faktur

Pendapatan Proyek

20\% X Rp 4.302.525.500,- = Rp 860.505.100,-

PPN

$10 \%$ X Rp 860.505.100,- $=$ Rp 86.050.510,-

Potongan PPH Final

$3 \%$ X Rp 860.505.100,- $=(\underline{\operatorname{Rp} 25.815 .153,-)}$

Kas yang diterima $\quad$ Rp 920.740.457,-

Termin I, Jurnal saat realisasi penerimaan termin

Dr. Kas

Rp 460.370.229,-

Dr. PPh Final

Rp 12.907.576,- 
Cr. Piutang Usaha $\quad$ Rp 473.277.805,-

Perhitungan;

Pendapatan proyek

$10 \%$ X Rp4.302.525.500,- $=\operatorname{Rp} 430.252 .550,-$

PPN

$10 \%$ X Rp 430.252.550,- = Rp 43.025.255,-

Potongan PPH Final

$3 \%$ X Rp 430.252.550,- $=\underline{(\operatorname{Rp} 12.907 .576,)}$

Kas yang diterima $\quad \mathrm{Rp} 460.370 .229$,-

Termin II, Jurnal saat realisasi penerimaan

Dr. Kas $\quad$ Rp 1.381.110.686,-

Dr. PPh Final Rp 38.722.729,-

Cr. Piutang Usaha Rp 1.419.833.415,-

Perhitungan:

Pendapatan proyekroyek

30\% X Rp 4.302.525.500,- = Rp 1.290.757.650,-

PPN

10\% X Rp 1.290.757.650,- = Rp 129.075.765,-

Potongan PPH Final

$3 \%$ X Rp 1.290.757.650,- $\quad=\left(\begin{array}{ll}\operatorname{Rp} \quad 38.722 .729,-\end{array}\right)$

Kas yang diterima $\quad \mathrm{Rp} 1.381 .110 .686,-$

Termin III, Jurnal saat realisasi penerimaan termin

Dr. Kas $\quad$ Rp 920.740.457,-

Dr. PPh Final Rp 35.815.153,-

Cr. Piutang Usaha Rp 956.555.610,-

Perhitungan:

Pendapatan Proyek

20\% X Rp 4.302.525.500,- = Rp 860.505.100,-

PPN

$10 \%$ X Rp 860.505.100,- = Rp 86.050.510,-

Potongan PPH Final

$3 \%$ X Rp 860.505.100,- $\quad=\underline{(\operatorname{Rp} 25.815 .153,-)}$

Kas yang diterima $\quad$ Rp 920.740.457,-

Termin IV, Jurnal saat realisasi penerimaan termin

Dr. Kas $\quad$ Rp 690.555.343,-

Dr. PPh Final Rp 19.361.365,-

Cr. Piutang Usaha Rp 709.916.708,- 
Perhitungan:

Pendapatan proyek

15\% X Rp 4.302.525.500,- $=\operatorname{Rp} 645.378 .825,-$

PPN

$10 \%$ X Rp 645.378.825,- = Rp 64.537.883,-

Potongan PPH Final

$3 \%$ X Rp 645.378.825,- $=\underline{(\operatorname{Rp~19.361.365,-)~}}$

Kas yang diterima $\quad \operatorname{Rp~690.555.343,-~}$

Termin V, Jurnal saat realisasi penerimaan termin

Dr. Kas $\quad$ Rp 230.185.113,-

Dr. PPh. Final Rp 6.453.788,-

Cr. Piutang Usaha Rp 236.638.901,-

Perhitungan:

Pendapatan proyek

$5 \%$ X Rp 4.302.525.500,- $\quad=\operatorname{Rp} 215.126 .275,-$

PPN 10\% X Rp 215.126.274,- = Rp 21.512.627,-

Potongan PPH Final

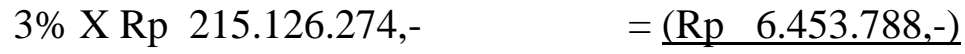

Kas yang diterima $\quad \operatorname{Rp} 230.185 .114,-$

\section{Pengakuan beban pada PT. Sumber Barokah}

Pengklasifikasian biaya kontrak PT. Sumber Barokah dapat dijabarkan sebagai berikut:

1. Biaya yang berhubungan langsung, terdiri dari:
a. Biaya bahan baku
b. Biaya Upah
c. Biaya subkontraktor
d. Biaya Peralatan
e. Biaya perlengkapan
f. Biaya transportasi

2. Biaya yang dapat didistribusikan pada aktivitas kontrak secara umum dan dapat dialokasikan pada kontrak tersebut, terdiri dari:
a. Asuransi
b. Biaya angkut
c. Telepon/komunikasi

\section{Pengukuran beban}

Dalam pembangunan Ciamis Mall, PT. Sumber Barokah mengeluarkan biaya sebesar Rp 3.435.756.500,-- 
Tabel 4

Beban Proyek Ciamis Mall

\begin{tabular}{|l|l|l|}
\hline Keterangan & Total Beban & Jumlah Beban \\
\hline Uang muka (20\%) & Rp 3.435.756.500 & Rp 687.151.300 \\
\hline Termin I (10\%) & Rp 3.435.756.500 & Rp 343.575.650 \\
\hline Termin II (30\%) & Rp 3.435.756.500 & Rp 1.030.726.950 \\
\hline Termin III (20\%) & Rp 3.435.756.500 & Rp 687.151.300 \\
\hline Termin IV (15 \%) & Rp 3.435.756.500 & Rp 515.363.475 \\
\hline Termin V (5 \%) & Rp 3.435.756.500 & Rp 171.787.825 \\
\hline TOTAL & & Rp 3.435.756.500 \\
\hline
\end{tabular}

Sama halnya dengan pendapatan, beban juga diukur berdasarkan persentase penyelesaian yang dicapai. Pada saat uang muka $20 \%$ beban yang diakui oleh perusahaan juga sebesar $20 \%$ dari total biaya proyek. Persentase penyelesaian di termin I sebesar 30\%, maka total beban yang dikeluarkan oleh perusahaan juga sebesar $30 \%$ dari total biaya proyek ( uang muka $20 \%$ + Termin I (10\%) ). Pada termin ke II beban yang diakui sebesar 30\% dari keseluruhan total biaya proyek dan persentase penyelesaian mencapai $60 \%$. Termin ke III beban yang diakui sebesar $20 \%$ dari keseluruhan total biaya proyek dan persentase penyelesaian mencapai $80 \%$. Termin ke IV beban yang diakui sebesar $15 \%$ dari keseluruhan total biaya proyek dan persentase penyelesaian mencapai 95\%. Di termin ke $\mathrm{V}$ beban diakui sebesar 5\% dari keseluruhan total biaya proyek dan persentase penyelesaian mencapai $100 \%$.

\section{Pencatatan Beban}

\section{Uang muka}

a. Jurnal saat pengakuan biaya proyek

Dr. Biaya Proyek Rp 687.151.300,-

Cr. Biaya yang harus dibayar Rp 687.151.300,-

b. Jurnal saat pembayaran utang atas biaya proyek

Dr. Biaya yang harus dibayar $\quad \mathrm{Rp} 687.151 .300,-$

\section{Termin I}

$$
\text { Cr. Kas/ Bank Rp 687.151.300,- }
$$

a. Jurnal saat pengakuan biaya proyek

Dr. Biaya Proyek Rp343.575.650,-

Cr. Biaya yang harus dibayar Rp 343.575.650,-

b. Jurnal saat pembayaran utang atas biaya proyek

Dr. Biaya yang harus dibayar Rp 343.575.650,-

$$
\text { Cr. Kas/ Bank Rp 343.575.650,- }
$$

\section{Termin II}

a. Jurnal saat pengakuan biaya proyek

Dr. Biaya Proyek Rp 1.030.726.950,-

Cr. Biaya yang harus dibayar Rp 1.030.726.950,- 
b. Jurnal saat pembayaran utang atas biaya proyek

Dr. Biaya yang harus dibayar $\mathrm{Rp} \quad 1.030 .726 .950,-$

$$
\text { Cr. Kas/ Bank Rp. 1.030.726.950,- }
$$

\section{Termin III}

a. Jurnal saat pengakuan biaya proyek

Dr. Biaya Proyek Rp 687.151.300,-

$$
\text { Cr. Biaya yang harus dibayar } \quad \text { Rp 687.151.300,- }
$$

b. Jurnal saat pembayaran utang atas biaya proyek

Dr. Biaya yang harus dibayar Rp 687.151.300,-

$$
\text { Cr. Kas/ Bank Rp 687.151.300,- }
$$

\section{Termin IV}

a. Jurnal saat pengakuan biaya proyek

Dr. Biaya Proyek Rp 515.363.475,-

$$
\text { Cr. Biaya yang harus dibayar } \quad \text { Rp 515.363.475,- }
$$

b. Jurnal saat pembayaran utang atas biaya proyek

Dr. Biaya yang harus dibayar Rp 515.363.475,-

\section{Termin V}

$$
\text { Cr. Kas/ Bank Rp 515.363.475,- }
$$

a. Jurnal saat pengakuan biaya proyek

Dr. Biaya Proyek Rp 171.787.825,-

Cr. Biaya yang harus dibayar $\quad$ Rp 171.787.825,-

b. Jurnal saat pembayaran utang atas biaya proyek

Dr. Biaya yang harus dibayar Rp 171.787.825,-

$$
\text { Cr. Kas/ Bank Rp 171.787.825,- }
$$

\section{Pengaruh Pengakuan Pendapatan dan Beban Terhadap Laporan Laba Rugi}

Dalam mengakui pendapatan atas jasa konstruksi, PT. Sumber Barokah menggunakan metode persentase penyelesaian dengan ukuran output. Dalam penentuan persentase penyelesaian dengan ukuran output ini perusahaan melibatkan insinyur dan arsitek dalam menafsirkan persentase penyelesaiannya. Perusahaan menganggap dengan penggunaan ukuran output persentase tingkat kemajuan yang telah dicapai secara fisik lebih mendekati kebenaran.

Tabel 4.5 - Tabel 4.8 dibawah ini akan menggambarkan laba kotor yang diterima perusahaan atas proyek Ciamis Mall: 
Tabel 5

Perhitungan laba kotor tahun 2011

\begin{tabular}{|c|l|l|l|}
\hline No & Keterangan & \multicolumn{2}{|c|}{2011} \\
\cline { 3 - 4 } & & Uang Muka & Termin I (30\%) \\
\hline 1 & Pendapatan & 860.505 .100 & 430.252 .550 \\
\hline 2 & Total biaya proyek & 687.151 .300 & 343.575 .650 \\
\hline 3 & Laba Kotor & 173.353 .800 & 86.676 .900 \\
\hline
\end{tabular}

Tabel 6

Perhitungan laba kotor tahun 2012

\begin{tabular}{|c|l|c|c|}
\hline \multirow{2}{*}{ No } & \multicolumn{1}{|c|}{ Keterangan } & \multicolumn{2}{|c|}{2012} \\
\cline { 3 - 4 } & & $\begin{array}{c}\text { Termin II } \\
(\mathbf{6 0 \%})\end{array}$ & $\begin{array}{c}\text { Termin III } \\
\mathbf{( 8 0 \% )}\end{array}$ \\
\hline \multirow{2}{*}{1} & Pendapatan & 1.290 .757 .650 & 860.505 .100 \\
\hline 2 & Total biaya proyek & 1.030 .726 .950 & 687.151 .300 \\
\hline 3 & Laba Kotor & 260.030 .700 & 173.353 .800 \\
\hline
\end{tabular}

Tabel 7

Perhitungan laba kotor tahun 2013

\begin{tabular}{|c|l|c|c|}
\hline \multirow{2}{*}{ No } & \multicolumn{1}{|c|}{ Keterangan } & \multicolumn{2}{|c|}{2011} \\
\cline { 3 - 4 } & & $\begin{array}{c}\text { Termin IV } \\
(\mathbf{9 5 \%})\end{array}$ & $\begin{array}{c}\text { Termin V } \\
\mathbf{( 1 0 0 \% )}\end{array}$ \\
\hline \multirow{2}{*}{1} & Pendapatan & 645.378 .825 & 215.126 .275 \\
\hline 2 & Total biaya & 515.363 .475 & 171.787 .825 \\
\hline
\end{tabular}




\begin{tabular}{|l|l|l|c|}
\hline & proyek & & \\
\hline 3 & Laba Kotor & 130.015 .350 & 43.338 .450 \\
\hline
\end{tabular}

Tabel 8

Perhitungan laba kotor tahun 2011-2013

\begin{tabular}{|c|c|c|}
\hline No & Keterangan & Total Laba kotor \\
\hline 1 & Pendapatan & $\mathbf{4 . 3 0 2 . 5 2 5 . 5 0 0}$ \\
\hline 2 & $\begin{array}{c}\text { Total biaya } \\
\text { proyek }\end{array}$ & $\mathbf{3 . 4 3 5 . 7 5 6 . 5 0 0}$ \\
\hline 3 & Laba Kotor & $\mathbf{8 6 6 . 7 6 9 . 0 0 0}$ \\
\hline
\end{tabular}

Gambar 1

Grafik laba kotor per tahun atas proyek Ciamis Mall

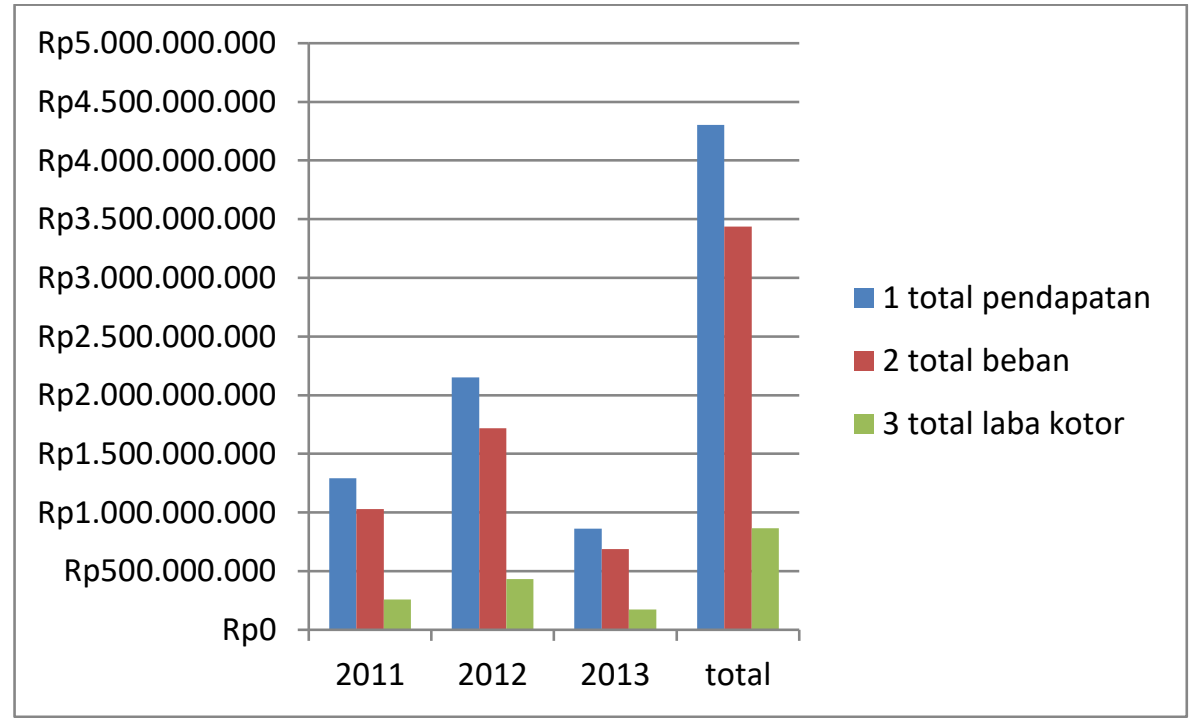


Dari grafik diatas terlihat perusahaan mengalami kenaikan dan penurunan laba kotor atas proyek Ciamis Mall setiap tahunnya, hal ini dikerenakan persentase penerimaan pendapatan dan pengeluaran biaya proyek berbeda-beda setiap terminnya. Dalam satu tahun, perusahaan menerima dua kali termin pembayaran atas proyek tersebut. Laba ditahun 2011 lebih rendah dibandingkan tahun 2012, hal ini dikarenakan pada penerimaan uang muka perusahaan tidak mengakui adanya beban karena belum ada prestasi kerja yang dihasilkan, prestasi kerja terjadi pada termin I yaitu sebesar $30 \%$.

\section{Penerapan PSAK No. 34 Atas Pengakuan Pendapatan dan Beban Terhadap Laporan Laba Rugi Pada PT.Sumber Barokah}

Berdasarkan PSAK No. 34 paragraf 30, tahap penyelesaian suatu kontrak dapat ditentukan dalam berbagai cara. Entitas menggunakan metode yang mengukur secara andal pekerjaan yang telah dilakukan, salah satu metodenya adalah survei atas pekerjaan yang telah dilaksanakan. Atas dasar tersebut penerapan metode persentase penyelesaian dengan ukuran output yang dilakukan oleh PT. Sumber Barokah telah sesuai dengan PSAK No. 34 (revisi 2010).

Selanjutnya pada paragraf 25 PSAK No. 34 menyatakan bahwa menurut metode persentase penyelesaian, pendapatan kontrak dihubungkan dengan biaya kontrak yang terjadi dalam mencapai tahap penyelesaian tersebut, sehingga pendapatan, beban, atau laba yang dilaporkan dapat diatribusikan menurut penyelesaian pekerjaan.

Hal ini terlihat ketika perusahaan memperoleh pendapatan kontrak atas proyek CIAMIS MALL sebesar Rp 4.302.525.500,- dan biaya atas proyek tersebut sebesar Rp 3.435.756.500,dan memperoleh laba atas proyek tersebut sebesar Rp888.769.000,-.tahun 2012, dikarenakan perusahaan menerima pendapatan atas proyek tersebut sebesar $50 \%$ dari nilai kontrak, persentase tersebut merupakan akumulasi atas termin ke II dan ke III yaitu sebesar 30\% dan $20 \%$, begitu juga halnya dengan biaya proyek yang dikeluarkan perusahaan ditahun 2012 sebesar 50\% dari keseluruhan total biaya proyek. Laba yang paling rendah terjadi ditahun 2013, karena ditahun ini perusahaan hanya menerima pendapatan sebesar $20 \%$ dari nilai kontrak yaitu dari termin ke IV sebesar $15 \%$ dan termin ke V sebesar $5 \%$.

\section{KESIMPULAN}

Berdasarkan hasil analisis diatas, maka penulis dapat menarik beberapa kesimpulan dan saran sebagai berikut:

1. Pengakuan pendapatan dan beban perusahaan menggunakan metode persentase penyelesaian dengan ukuran output. Kenaikan dan penurunan laba disetiap tahunnya atas proyek yang dilakukan karena perbedaan persentase pendapatan dan beban setiap terminnya.

2. Pengakuan pendapatan dan beban serta metode pencatatan dan pengukuran yang diterapkan oleh PT. Sumber Barokah sudah sesuai dengan standard akuntansi yang berlaku yaitu Pernyataan Standard Akuntansi Keuangan(PSAK) dalam hal ini yang terkait dengan kontrak konstruksi adalah PSAK No. 34.

3. Uang muka yang diterima oleh perusahaan atas suatu proyek langsung diakui sebagai pendapatan diterima dimuka.

\section{SARAN}


Setelah ditarik kesimpulan atas analisis seperti tersebut diatas, maka dibagian ini penulis memiliki beberapa saran untuk perbaikan perusahaan, yaitu:

1. Perusahaan harus mengevaluasi biaya-biaya yang terlalu tinggi dalam pengalokasian beban ditahun berjalan agar laba yang didapat lebih maksimal.

2. Perusahaan harus tetap konsisten dalam menerapkan PSAK No. 34 atas kontrak konstruksi

3. Perusahaan bisa lebih mengembangkan lagi tentang kebijakan akuntansi yang diterapkan dalam perusahaan, namun tetap harus sesuai dengan standard yang berlaku.

\section{DAFTAR PUSTAKA}

Donald E, dkk. 2008. Akuntansi Intermediate, edisi dua belas, jilid satu, Erlangga, Jakarta.

Garisson, dkk.2008.Akuntansi Manajerial, edisi sebelas, jilid dua, salemba empat, Jakarta.

Ikatan Akuntansi Indonesia. 2012. Pernyataan Standard Akuntansi Keuangan, Salemba empat, Jakarta

Prihantara Ida Bagus Teddy. 2009. Sistem Akuntansi Perusahaan Konstruksi, Graha Ilmu, Jakarta.

Silitonga Fina Prayerty.2012.Analisis Penerapan PSAK No. 34(Revisi 2010) Atas Pengakuan Pendapatan dan Beban Perusahaan Konstruksi Pada PT. TPHE. Jakarta: Jurnal Penelitian

Skouse, Stice. 2009. Akuntansi Keuangan, Edisi 16. Salemba empat, Jakarta

William K. Charter and Miltin F. Usry. 2008. Akuntansi Biaya. salemba empat, Jakarta.

Suherman.2005.Siklus Akuntansi Perusahaan Jasa dan Dagang. PT.TransMandiri Abadi, Jakarta

Hanafi Mamduh M, Halim Abdul. 2009.Analisis Laporan Keuangan.UPP STIM YKPN, Yogyakarta

Wiliam k. Charter.2009. Akuntansi Biaya, buku satu, edisi 14. Salemba Empat, Jakarta 
